\title{
Spatial and temporal distribution of pelagic microorganisms and their proteolytic activity over a partly destroyed coral reef
}

\author{
H.-G. Hoppe ${ }^{1}$, W. Schramm ${ }^{1}$, P. Bacolod ${ }^{2}$ \\ ${ }^{1}$ Institut für Meereskunde an der Universität Kiel, Düsternbrooker Weg 20, D-2300 Kiel, Federal Republic of Germany \\ ${ }^{2}$ Marine Laboratory, University of San Carlos, Cebu City, Philippines
}

\begin{abstract}
Bacterial number, biomass and exoproteolytic activity were determined in the surface water of a coral reef near Bohol (Philippines). Bacteriological results from this partly destroyed reef (seaweed farming) were compared with literature values from healthy reef systems. While total bacterial numbers were more or less evenly distributed over the reef transects, saprophytes and proteolytic activities showed distinct increases at the reef crest and also at the reef lagoon boundary These were the only undisturbed parts of the reef. It is suggested that coral mucus with its high content of proteinaceous organic matter is a major source of nutrients for bacteria in the water column over the reef. Specific exoproteolytic activity per bacterial cell was considerably higher in the water over the healthy parts of the reef than over the disturbed parts and also higher than in waters from temperate zones.
\end{abstract}

\section{INTRODUCTION}

Coral reefs are highly productive systems, and the role of microorganisms in commurity maintainance seems to be even greater here than in other shallow water environments. However, due to their high degree of specialization and interrelation coral reefs are also very much affected by environmental stress factors. Consequences of stress for the reef community have been described as follows, by DiSalvo \& Odum (1974): 'as with other highly structured natural communities, a disorganizing influence applied to a vital community structure or function may prove disastrous to the entire system, the ruins of which may emerge as a new system of altered structure with changed esthetic and economic values'. Nowadays, human activities - such as removal of corals and molluscan shells, extensive fishing by destructive fishing practices and farming projects - are among the most serious stress factors affecting coral reef systems. It has even been claimed that the most dangerous natural enemy of coral colonies, the crown-of-thorns starfish Acanthaster planci, took advantage of man-made changes in the coral reef community structure (Ryan 1985).

Microbiological investigations of coral reefs have mainly been performed in intact Systems. There is more or less detailed information on bacterial numbers and biomasses, production and uptake activities which normally occur in reefs and their sub-biotopes. Not so much is known about the involvement of microbes in regenerative nutrient cycles of reef systems, nor of course of specific interrelationships between bacteria and single species of the reef community. It is also an open question how the microbial reef population reacts to reef destruction. If bacterial populations play a prominent role as food and as nutrient regenerators in the reef community, their reduction will certainly affect some feedback mechanisms, which are important for coral reef proliferation and survival (DiSalvo 1971, Sorokin 1973).

The coral reef under observation was not an undisturbed natural biotope. It was relatively intact at its seaward crest, whereas the reef flat was partly cleared of its natural biota. In its place, extensive seaweed farming (Eucheuma) had been established on the sandy flat of the reef. This reef was surveyed for microbiological and related parameters at transect stations which covered the disturbed and undisturbed parts of the reef. It was the aim of this preliminary study to investigate whether or not bacterial distribution 
patterns frequently found in the water of intact coral reefs are preserved in a partly destroyed reef system, and to compare quantities of bacteria and bacterial activity with those of intact reefs.

\section{MATERIALS AND METHODS}

Experimental site. The investigations were carried out at a seaweed farm site of Genu Oceanfarming Corp. in April 1986. The 30 ha Genu farm is located together with some 70 other, smaller, farms on Danajon Bank north of Bohol (Central Visayas, Philippines; Fig. 1). The bank is a coral reef system stretching $40 \mathrm{~km}$

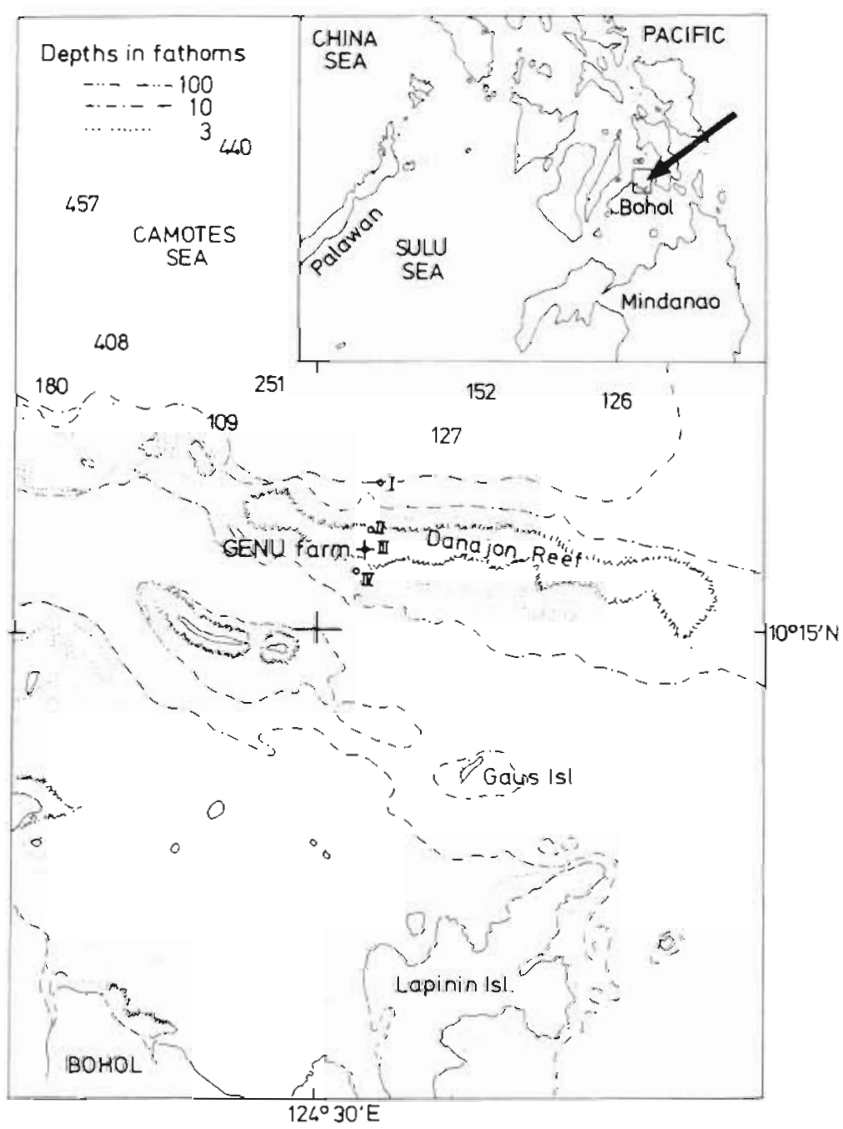

Fig. 1. Danajon reef in the archipelago north of Bohol (Philippines), showing the GENU seaweed farm on the reef plain and (I to IV) transect stations

from west to east, and 1 to $2 \mathrm{~km}$ from south to north. The reef is flushed twice a day by strong tidal currents in alternating $\mathrm{N}-\mathrm{S}$ directions. Average current speed as determined with Aleksejew current meters was $0.2 \mathrm{~m}$ $\mathrm{s}^{-1}$. A residual current of approximately $0.03 \mathrm{~m} \mathrm{~s}^{-1}$ was observed in SW direction. Mean tidal fluctuations were $2 \mathrm{~m}$ with average depth $0.5 \mathrm{~m}$ at low tide and $2.5 \mathrm{~m}$ at high tide.
The farm site consists of natural coral reef communities with sandy and coral patches. Half of the area has been thoroughly cleared of coral rocks and vegetation for Eucheuma monoline culture. Approximately one third of the farm area was being used for farming at the time of the experiments.

Sampling. Subsurface water samples were taken in autoclaved 21 glass bottles at 4 different stations of a transect in N-S direction over the reef area (Fig. 1). Three successive samplings were made, representing 2 different tidal regimes.

Saprophytes. Bacteria forming colonies on rich media were determined on ZoBell-agar, prepared with prefiltered and autoclaved seawater from an unpolluted site. Aged seawater as normally used for this purpose or artificial seawater was not available. Triplicates of plates were run of undiluted sample water and of $10^{-1}$ dilutions. Due to lack of incubators, agar plates were incubated at ambient temperature 128 to $30^{\circ} \mathrm{C}$ ) in the dark and colonies were counted after $7 \mathrm{~d}$.

Total number of bacteria and microbial biomass. Subsamples were stored in thoroughly cleaned scintillation vials and fixed with formaldehyde of final concentration $2.0 \%$. They were analyzed for microbial numbers and biomass by using acridine-orange direct count (AODC) techniques (Zimmermann \& Meyer-Reil 1974, Hobbie et al. 1977) in our laboratory at Kiel, FRG. Total biomass of bacteria was calculated by measuring length and width of the bacteria, and arranging them in size classes. Carbon content was then computed on the basis that $20 \%$ of bacteria wet weight is dry matter and $50 \%$ of this is carbon.

Determination of extracellular protease activity. Extracellular enzyme activities were determined by using fluorogenic model substrates according to Hoppe (1983). In brief, the method is as follows. The model substrate for protease activity was L-leucine-methylcoumarinylamid (leu-MCA). Water samples $(20 \mathrm{ml})$ were supplemented with dilutions of this substrate, giving final concentrations of $0.1,1,10,125$ and $250 \mu \mathrm{M}$ $1^{-1}$.

Decomposition of the model substrate, which is achieved mainly by bacterial extracellular enzymes, causes an accumulation of methyl-courmarinylamid (MCA) in the water. MCA is the fluorescing compound of the combined non-fluorescent molecule Leu-MCA. Its liberation by proteases from the combined molecule (model substrate) is equivalent to the production of free leucine from the model substrate.

The MCA concentration in the water was measured in a fluorometer at $364 \mathrm{~nm}$ excitation and $445 \mathrm{~nm}$ emission wavelength. A filter fluorometer (Turner, B111, excitation filter No. 813, emission filter No. 820) was used for the measurement of fluorescence intensity. This instrument has of course a lower selectivity 
than a modern spectrofluorometer. Due to the different slits and light reduction filters needed for these fluorescence measurements, several calibration lines of MCA fluorescence were established. Extracellular enzyme activities of proteases follow, in most cases, the rules of first-order enzyme kinetics, as described by Hoppe (1983, 1986). After Lineweaver-Burk transformation of the raw data, extracellular enzyme activities were expressed in terms of $V_{\mathrm{m}}\left(\mu \mathrm{g} \mathrm{C} \mathrm{l}^{-1} \mathrm{~h}^{-1}\right)$ for leucine liberation from the model substrate. Furthermore the rate of hydrolysis $H_{\mathrm{r}}\left(\% \mathrm{~h}^{-1}\right)$ was calculated, which is the percentage of the naturally occurring protein pool hydrolyzed by extracellular enzymes within $1 \mathrm{~h}$ of incubation. Of course only that part of the natural protein pool is included which is represented by the model substrate. Unfortunately this fraction is not at present well defined.

\section{RESULTS}

\section{Microbiological parameters}

The first transect was made during high tide (9 April $1986,13: 00 \mathrm{~h}$ ). The water current was southward, so that watermasses from the open sea were transported across the reef crest and the reef flat to the reef lagoon. Results of bacteria abundance and extracellular enzyme activities are shown in Fig. 2a. Total bacterial numbers and microbial biomasses were extremely low all over the reef $\left(51\right.$ to $76 \times 10^{3} \mathrm{mi}^{-1} ; 0.52$ to $0.89 \mu \mathrm{g} \mathrm{C}$ $1^{-1}$ ). A small increase could be recognized at the windward side of the reef, while average cell biomass seemed to increase slightly at the lagoon side. However, at these low numbers the AODC counting procedure becomes critical and it is uncertain whether or not the numbers and biomass from the different stations differ significantly from each other. Saprophyte numbers were also very low (26 to $192 \mathrm{ml}^{-1}$ ). They showed a weak tendency to increase at the northern reef crest. This tendency is expressed much more strongly by the exopeptidase activity which is about 10 times higher at the reef boundaries than on the reef flat (range $V_{\mathrm{m}}$ : 0.11

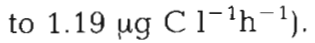

The second transect was made during low tide (10 April 1986; 07:30 h). Water masses were transported northward from the inner lagoon across the reef to the open sea. Microbiological results are shown in Fig. 2b. Saprophyte numbers were low, but were significantly higher at the inner and outer boundaries of the reef $(72$ to $788 \mathrm{ml}^{-1}$ ). Total bacterial numbers and bacterial biomass were very similar to those obtained at high tide the day before $\left(57\right.$ to $87 \times 10^{3} \mathrm{ml}^{-1} ; 0.51$ to $0.89 \mu \mathrm{g}$ $\mathrm{C}^{-1}$ ). A small increase of total bacteria numbers was observed at the lagoon side of the reef, which was probably caused more by the high bacteria load of the incoming lagoon water than by the reef community itself. Exopeptidase activities of bacteria were considerably higher at the outer and inner boundaries of the reef than on the flat. At most stations they were higher than during high tide (range $V_{\mathrm{m}}: 0.24$ to $1.63 \mu \mathrm{g} \mathrm{C}$ $\left.\mathrm{l}^{-1} \mathrm{~h}^{-1}\right)$.

The third transect was made again at high tide $(10$ April 86; 13:00 h), during the period of southward water transport. Results of bacterial abundance and extracellular enzyme activities are shown in Fig. 2c. Total bacterial numbers and microbial biomass were extremely low all over the reef $\left(40\right.$ to $73 \times 10^{3} \mathrm{ml}^{-1} ; 0.66$ to $0.75 \mu \mathrm{g} \mathrm{C}^{-1}$ ), slightly lower than during low tide. The saprophytes show a more distinct pattern of distribution (range: 55 to $1073 \mathrm{ml}^{-1}$ ). Maximal numbers recorded at the outer and inner boundaries of the reef were about 10 times higher than those found on the reef flat. Possible local polluting influences from the seaweed-farm platform (Station III) were not reflected by in saprophyte counts. Peptidase activities of bacteria were considerably higher at the reef crest than on the

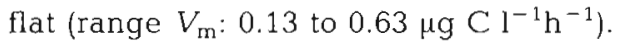

Rates of hydrolysis of peptides by bacterial exopeptidases in the water above the reef as measured by Lineweaver-Burk extrapolation ranged from 0.03 to $1.0 \% \mathrm{~h}^{-1}$ with a mean value of $0.22 \% \mathrm{~h}^{-1}$. There was no correlation between $V_{\mathrm{m}}$ of peptidase activity and the rate of hydrolysis, which may be attributed to the high dynamics of water exchange and organic matter production in the reef.

The platform station was more frequently sampled than the other stations of the transects. This provided more detailed information on tidal variations of bacterial numbers on the reef flat. Results are presented in Table 1. At low tide water depth at the platform station was about $0.50 \mathrm{~m}$, at high tide it increased to $2.00 \mathrm{~m}$. Saprophyte numbers were very low at this station at all times. Nevertheless they were higher at low tide than at high tide, when the microbiological situation on this reefs seems to be truly oceanic. Total numbers of bacteria and microbial biomass were also slightly higher at low tide than at high tide. However, (especially for the biomass determinations) these differences may not be statistically significant.

In general, bacterial numbers at the platform station were in the range of those obtained from the other reef flat station (Station II) of the transects. They were smaller than bacterial numbers from the reef crest stations. The platform station is surrounded by seaweed farming areas. Obviously farming activities do not have a pronounced effect on bacteria abundance and peptidase activity on the reef flat. They are at least smaller than tidal influences or those caused by the windward and leeward reef biota. 


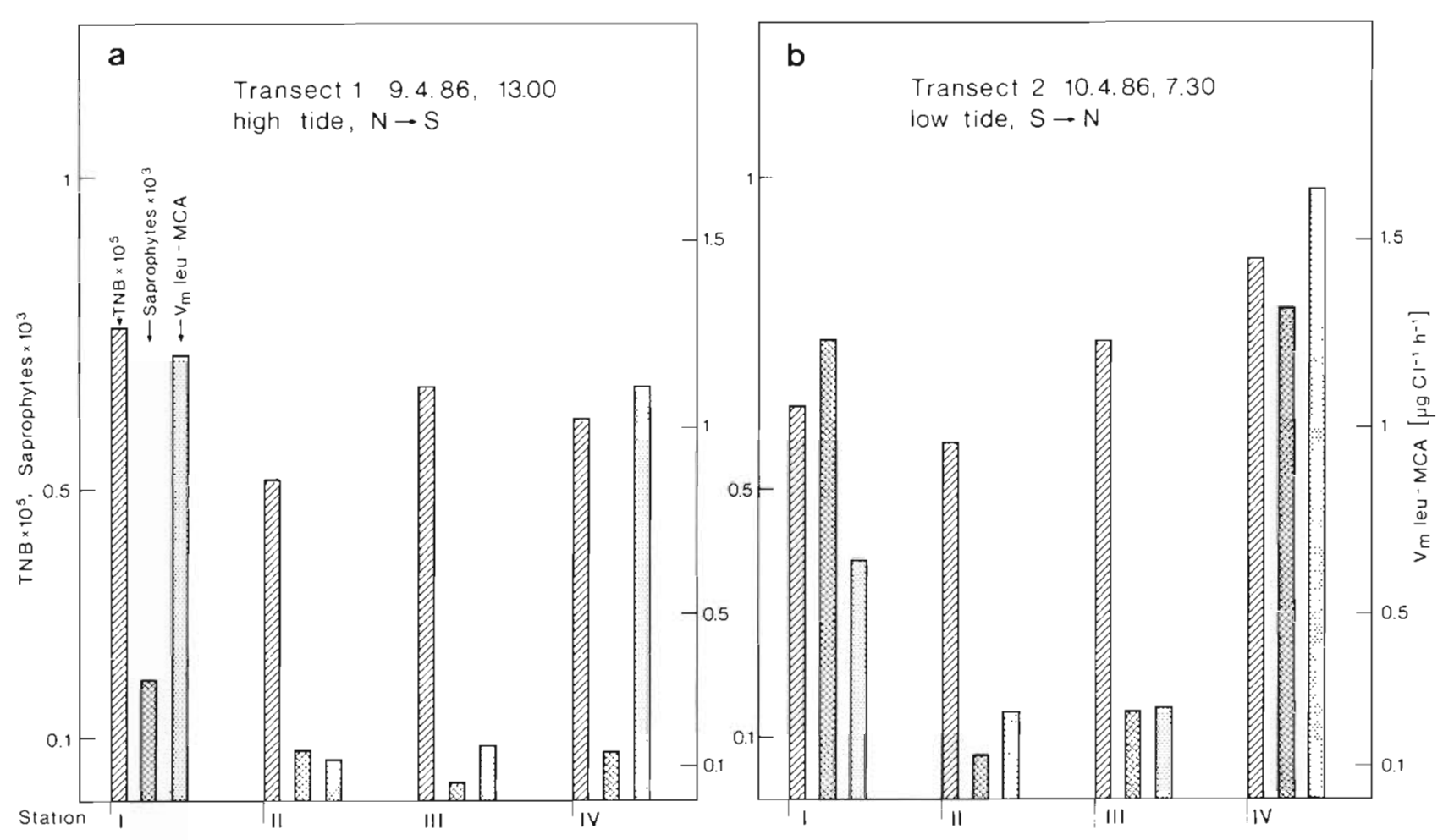

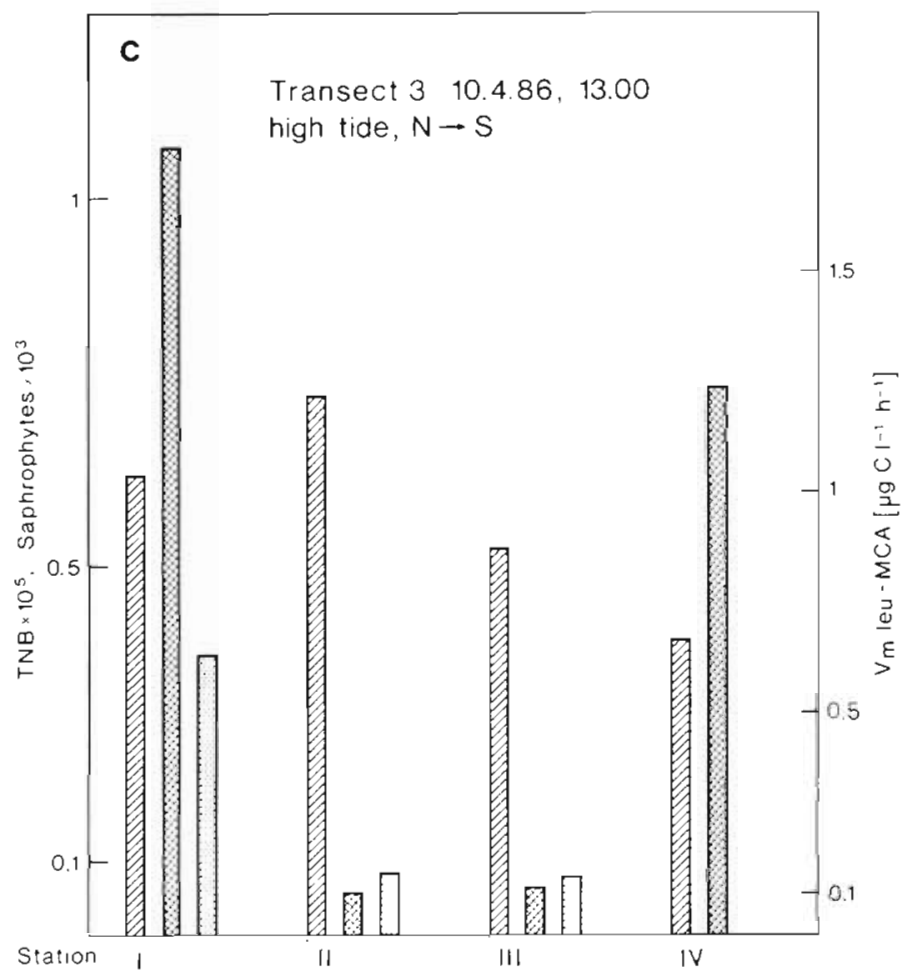

Fig. 2. Microbiological results from the 3 transects (Stns I to IV) made over the Danajon coral reef. Parameters: TBN $\times 10^{5}$ (shaded bars) $=$ total number of bacteria $\times$ $10^{5}$ per ml; saprophytes $\times 10^{3}$ (cross-hatched bars) $=$ saprophytes $\times 10^{3}$ per ml; $V_{m}$ leu-MCA $\left(\mu g \mathrm{Cl}^{-1} \mathrm{~h}^{-1}\right)$ (stippled bars) $=$ potential of extracellular peptide hydrolysis by bacteria. (a) High tide (water current direction from open sea to lagoon, $\mathrm{N} \rightarrow \mathrm{S}$ ). All 3 parameters were highest at the reef crest (Stn I), the only intact part of the reef. (b) Low tide (water current direction from lagoon to open sea, $\mathrm{S} \rightarrow \mathrm{N}$ ). Water masses from the lagoon heavily influenced microbial activities at the inner part of the reef (Stn IV). Nevertheless measurements from the reef crest (Stn I) were also markedly high. (c) High tide (water current direction $\mathrm{N} \rightarrow \mathrm{S}$ ). Note relatively high abundance of saprophytes in relation to total numbers of bacteria at the reef crest and also at the lagoon side station. For more detailed explanation see text

\section{DISCUSSION}

Every coral reef has its own characteristics and the abundance and activity of its microbiota depends on a number of factors: geographical situation and spatial dimension of the reef, strength and direction of water currents over the reef, temperature variations over the year, and degree of destruction by human activities. Furthermore the community structure and the morphological structure of reefs are very complex, which 
Table 1. Measurements of bacterial parameters at low tide (LT) and high tide (HT) in the water at the platform station (Stn III) (reef flat) of the Genu coral reef. Saprophytes: saprophytes per ml; TNB: total number of bacteria per ml; TBB: total bacterial biomass $\left(\mu \mathrm{g} \mathrm{C} 1^{-1}\right)_{i}$ EEA. extracellular enzyme activity of bacterial peptidases as measured by leu-MCA hydrolysis $\left(V_{\mathrm{m}} \mu_{\mathrm{g}} \mathrm{Cl}^{-1} \mathrm{~h}^{-1}\right)$

\begin{tabular}{|lcccccc|}
\hline Parameter & \multicolumn{3}{c}{} & 9 April 1986 & & 10 April 1986 \\
& $05: 00 \mathrm{~h} \mathrm{LT}$ & $13: 00 \mathrm{~h} \mathrm{HT}$ & $17: 00 \mathrm{~h} \mathrm{LT}$ & $05: 00 \mathrm{~h} \mathrm{LT}$ & $07: 30 \mathrm{~h} \mathrm{LT}$ & $13: 00 \mathrm{~h} \mathrm{HT}$ \\
\hline Saprophytes & 188 & 26 & 155 & 139 & 140 & 62 \\
TNB & 116971 & 66407 & 96054 & 55497 & 73878 & 52292 \\
TBB & 1.03 & 0.73 & 0.89 & 0.65 & 0.89 & 0.66 \\
EEA & 0.62 & 0.15 & - & 0.80 & 0.25 & 0.132 \\
\hline
\end{tabular}

makes it nearly impossible to characterize their microbiological events by a small set of data. In the close neighbourhood of the reef, corals, macrophytes and microbes may be involved in a tight cycle of organic matter conversion (Paul et al. 1986). Measurements of microbiological parameters in overlying waters may reflect the result of nutrient and particle exchange between the incoming oceanic water masses and the reef surface organisms and sediments. Clearly the expected small-scale patchiness of microbial activity on the reef surface will be destroyed in the water column, due to water currents and mixing with surrounding water masses. Nevertheless measurements of microbial activities in the overlying waters will be related to the overall productivity of the reef system under observation (Johannes et al. 1983) and will allow a rough zonation of the reef structure, with respect to more or less productive areas.

Microbial abundance and acitivity ds measiured at the 3 transects over the Genu reef showed a clear tendency. Saprophyte numbers were generally higher at the reef crest and the lagoon side of the reef than on its flat. Total numbers of bacteria were occasionally higher at the reef crest: in general, however, they were more evenly distributed over the reef than the saprophytes. Exopeptidase activities of bacteria were highest at the reef crest, followed by a sharp decrease on the reef flat and a rise again at the lagoon side. A similar pattern of distribution, with respect to total bacteria numbers, has also been observed by other investigators of intact coral reef systems (e.g. Moriarty 1979, Moriarty et al. 1985a, Linley \& Koop 1986). Besides release of organic matter by macrophytes (Schleyer 1984, Schramm et al. 1984), mucus production by the corals - which probably serves to cleanse the organisms of sediment (Hubbard \& Pocock 1972) is an important source of organic matter export from the reef bottom organisms to the water column above the reef. The chemical composition of the latter varies between species, but proteins are always a major fraction of their dry matter content ( 5 to $73 \%$, Ducklow \& Mitchell 1979a); their C:N ratios are between 5.7 and 8.5 (Coles \& Strathmann 1973).
Measurements of microbial exopeptidase activities provide useful information on organic matter conversion which is even more closely related to specific coral reef factors than conventional experiments on bacterial heterotrophic substrate uptake. In the reef under observation, exopeptidase activity was strongest at the reef crest and on the lagoon side, the only parts of the reef not destroyed by human acitivities. The reef crest is also most directly exposed to tidal scour and wave action, factors which may favour mucus detachment from the corals and suspension into the water column. Values of exopeptidase activity coincided with highest saprophyte counts at the reef crest, where total bacteria numbers were not, or only slightly, higher than on the reef flat. This would suggest that mainly saprophytes would benefit from the coral reef releases, or that mucus particles, already colonized by bacteria at their place of origin, are suspended in the overlying waters. Duclslow \& Mitchell (1979h) reported that the mucus layers of some living corals are heavily colonized by communities of marine heterotrophic bacteria, which could be cultivated on agar media (1.5 to $3800 \times 10^{3}$ $\mathrm{ml}^{-1}$ mucus). Most of these were proteolytic and Vibrio alginolyticus was frequently the dominant strain. In the Genu reef only the reef crest is populated by a dense genuine coral population. It is therefore very likely that the increase in saprophyte numbers and the distinct peak of peptidase activity over this part of the reef is due to the export of mucus and its adherent microflora. On the 3 transects, saprophytes formed $0.3,1.2$ and $1.5 \%$ of the total number of bacteria at the reef crest station. They were in at least 2 cases considerably higher than the $0.2 \%$ normally found in offshore waters. On the other hand particulate materials were rare all over the reef and their population of attached bacteria was scarce. Mucus secreted by some coral species has been reported to be extremely diffuse and organized in transparent strands (Coles \& Strathmann 1973). Thus the lack of heavily colonized particles in the reef under observation may be attributed to rapid disintegration of the delicate mucus particles in the water column, which makes them invisible in the microscope. 
Though bacterial abundance on Danajon coral reef was generally much lower than in other more intact reef systems (Table 2), some weak tidal influences on this parameter could be observed. At the platform station on the reef flat saprophyte numbers were always considerably higher at low tide than at high tide, and to a lesser degree this tendency was also valid for total numbers of bacteria and their biomass. This effect may not only be attributed to the tidal influence but also to an unknown day and night cycle, because high tide samples were always taken at midday and low tide samples at daybreak. Meyer-Reil et al. (1981) found a similar diurnal cycle of heterotrophic glucose uptake in a coral reef in the same region. Linley \& Koop (1986) showed in a more extensive study on diel rhythms of microbial parameters in a Great Barrier reef environ- ment that there is no simple tide-dependent distribution pattern of bacterial abundance and activity. Our observations are also in contradiction with those of Crossland et al. (1980) and Schramm et al. (1984), who measured increasing rates of coral mucus production and macroalgal secretion of organic matter with increasing light intensity.

The reef under observation was heavily destroyed by human activities. Only the slope of its seaward crest was inhabited by typical reef community organisms. Nevertheless some phenomena typical for intact reef systems could also be observed in this environment. High microbial exopeptidase activities which were found in the water over the intact parts of the reef may be regarded as new and additional information, supporting our understanding of nutrient fluxes in coral

Table 2. Some measurements of bacterial parameters from coral reef environments. W/S: samples taken from water (W) or sediment (S): TNB: total number of bacteria per ml water $\times 10^{6}$; TBB: total bacterial biomass (mg $\mathrm{C} \mathrm{m}^{-3}$ water or mg C $\mathrm{g}^{-1}$ sediment); saprophytes: number of bacterial colonies on agar media per ml water or g sediment; BP: bacterial production ( $\mu \mathrm{g} C \mathrm{I}^{-1}$ $\mathrm{h}^{-1}$ [water] or $\mathrm{mg} \mathrm{C} \mathrm{m}^{-2} \mathrm{~d}^{-1}$ [sediment]); HP: heterotrophic potential for glucose uptake ( $\mu \mathrm{g} \mathrm{Cl}^{-1} \mathrm{~h}^{-1}$ ); EEA: extracellular enzyme activity for peptidases ( $\mu \mathrm{g} \mathrm{Cl}^{-1} \mathrm{~h}^{-1}$ of amino acid carbon). Figures from a rocky reef (no corals) of Natal (South Africa) are given for comparison only

\begin{tabular}{|c|c|c|c|c|c|c|c|c|}
\hline Region & W/S & TNB & TBB & Saprophytes & $\mathrm{BP}$ & $\mathrm{HP}$ & EEA & Source \\
\hline $\begin{array}{l}\text { Hawaii } \\
\text { Marshall Islands }\end{array}$ & $\begin{array}{l}\mathrm{S} \\
\mathrm{S}\end{array}$ & & & $\begin{array}{l}1.3-2.5 \times 10^{8} \\
0.6-10.2 \times 10^{8}\end{array}$ & & & & $\begin{array}{l}\text { DiSalvo \& Gun- } \\
\text { dersen } 1971\end{array}$ \\
\hline Marshall Islands & W & $0.8-2$ & $20-60$ & & & & & Sorokin 1973 \\
\hline Eilat, Israel & W & & & $350 \pm 70$ & & & & Ducklow \& \\
\hline Bermuda & W & & & $510 \pm 30$ & & & & Mitchell 1979b \\
\hline Barbados & W & & & $1550 \pm 640$ & & & & \\
\hline Great Barnier Reef & W & $\begin{array}{l}0.2-0.6 \\
\text { only free bact. }\end{array}$ & $20-60$ & & & & & Moriarty 1979 \\
\hline $\begin{array}{l}\text { Great Barrier Reef } \\
\text { reef flat } \\
\text { reef front } \\
\text { open water }\end{array}$ & $\begin{array}{l}W \\
W \\
W \\
W\end{array}$ & $1.1-2.5$ & & & $\begin{array}{l}0.05-2.33^{a} \\
0.06-1.08^{a} \\
0.03-0.46^{a}\end{array}$ & & & $\begin{array}{l}\text { Moriarty et al. } \\
1985 \text { a }\end{array}$ \\
\hline Great Barrier Reef & S & & 0.14 & & $120-370$ & & & $\begin{array}{l}\text { Moriarty et al. } \\
1985 b\end{array}$ \\
\hline Great Barrier Reef & W & $\begin{array}{l}0.12-1.3 \\
\text { av. } 0.48\end{array}$ & $\begin{array}{l}1.3-16 \\
\text { av. } 5.3\end{array}$ & & $\begin{array}{l}0.04-6.13 \\
\text { av. } 0.61\end{array}$ & & & $\begin{array}{l}\text { Linley \& Koop } \\
1986\end{array}$ \\
\hline Florida, USA & & & & & & & & Paul et al. 1986 \\
\hline Dry Tortugas & W & $0.26-0.63$ & & & $0.12-0.83$ & & & \\
\hline $\begin{array}{l}\text { coral surface } \\
\text { microlayer }\end{array}$ & $W$ & $0.5-1.94$ & & & $2.8-24.4^{b}$ & & & \\
\hline Key West & W & 0.17 & & & $14.6^{\mathrm{b}}$ & & & \\
\hline $\begin{array}{l}\text { coral surface } \\
\text { microlayer }\end{array}$ & W & 0.88 & & & $82.3^{b}$ & & & \\
\hline Philippines & W & & $0.51-1.03$ & & & & & \\
\hline reef flat & W & $0.05-0.12$ & & $26-188$ & & & $0.11-0.25$ & \\
\hline reef crest & W & $0.06-0.08$ & & $192-1073$ & & & $0.63-1.12$ & \\
\hline Natal rocky reef & W & $\begin{array}{l}1.0-2.7 \\
\text { av. } 2\end{array}$ & $\begin{array}{l}5.4-13.8 \\
\text { av. } 10.4\end{array}$ & & 1062 & $\begin{array}{l}0.01-1 \\
\text { av. } 0.26\end{array}$ & & Schleyer 1981 \\
\hline
\end{tabular}


reef systems. On the other hand there are consequences of long-term reef destruction which can only be evaluated when seen in comparison to undestroyed reef systems. For this we include our data in a list of microbial measurements made in a variety of microbial reef investigations (Table 2). A list like this cannot be a complete one and it is necessarily somewhat unprecise, because integrated figures on microbial abundance and activity suppress detailed information on specific spatial and temporal pattern distribution. The intention here is to provide an idea of the ranges of microbial numbers and activities which have been found in different healthy reef systems, and to show differences which may occur in a partly destroyed reef. Since the microbial population is a substantial part of the coral reef community, it can be concluded that changes in this population will also have a bearing on other reef organisms with respect to nutrition and substrate regeneration.

Total numbers of bacteria and their biomass in the water overlying the Genu reef were considerably smaller than in intact reef systems. Saprophytes, however, seem to be in the same range as in intact coral reefs, especially in those limited areas which have not been destroyed. Unfortunately there is only little information on saprophytes in coral reefs for comparison. This parameter seems to be closely related to coral mucus production, because mucus substrates are heavily colonized by bacteria which are also able to form colonies on agar media. Mucus detritus together with its epiphytic bacteria serves diso às food for recf zooplankton organisms (Gottfried \& Roman 1983). Thus, coral mucus is a subject of competition between microbial decomposition activities and zooplankton feeding activities. Because protein is a substantial component of coral mucus, microbial exopeptidase activity measurements provide a means of quantifying the bacterial contribution to coral mucus decomposition. Our data on exopeptidase activity (Table 2) show a great difference between the reef crest, where mucus producing organisms were abundant, and the reef flat. Unfortunately no values of this parameter are available from other reefs for comparison. Compared with exopeptidase activities from a less polluted shallow brackish water environment ( $V_{\mathrm{m}}: 0.29$ to 14.1 ; mean $4.46 \mu \mathrm{g} \mathrm{Cl}^{-1} \mathrm{~h}^{-1}$; Hoppe 1986), activities measured in the Genu reef water appear to be low. However, they are high in relation to bacterial numbers in the corresponding biotope (brackish water environment: saprophytes 100 to 12600 , mean 3100 ; total numbers of bacteria 0.5 to $2.5 \times 10^{6}$, mean $1.5 \times 10^{6}$ ). High activities combined with relatively low bacterial standing stock numbers have also been reported for bacterial reproduction rates in coral reefs (Moriarty et al. 1985a, Linley \& Koop 1986) and for heterotrophic substrate uptake in a rocky reef (Schleyer 1981). Our data on exopeptidase activity suggest that extracellular hydrolysis of macromolecular organic matter in an environment of rapid microbial turnover of monomeric substrate - as represented by the coral reef water column is important in organic nutrient generation for microbial usage. In the destroyed part of the reef, the reef flat, this coupling between nutrient release, bacterial decomposition of macromolecular organic matter and bacteria (saprophyte) abundance was not observed.

Acknowledgements. We thank Dr K. Koop (Stockholm) for his critical assessment of this manuscript. We also acknowledge the cooperation of students ( $F$. Torres, A. Batomalagues, $G$ Padajinog) from the 1986 training course in marine biology held at the San Carlos University in Cebu (Philippines).

\section{LITERATURE CITED}

Coles, S. L., Strathmann, R. (1973). Observations on coral mucus 'flocks' and their potential trophic significance Limnol. Oceanogr. 18: 673-678

Crossland, C. J., Barnes, D. J., Borowitzka, M. A. (1980) Diurnal lipid and mucus production in the staghorn coral Acropora acuminata. Mar. Biol. 60: 81-90

DiSalvo, L. H. (1971). Regenerative functions and microbial ecology of coral reefs: labelled bacteria in a coral reef microcosm. J. exp. mar. Biol. Ecol. 7: 123-136

DiSalvo, L. H., Gundersen, K. (1971). Regeneration functions and microbial ecology of coral reefs. I. Assays for microbial populations. Can. J. Microbiol. 8: 1081-1089

DiSalvo, L. H., Odum, H. T. (1974). Coral reefs. In: Odum, H T., Copeiand, B. J., ivícMahoñ, E. A. (cds.) Coastal ecological systems of the United States. The Conservation Foundation, Washington, p. 372-441

Ducklow, H. W., Mitchell, R. (1979a). Composition of mucus released by coral reef coelenterats. Limnol. Oceanogr. 24 (4): 706-714

Ducklow, H. W., Mitchell, R. (1979b). Bacterial populations and adaptions in the mucus layers on living corals. Limnol. Oceanogr. 24 (4): 715-725

Gottfried, M., Roman, M. R. (1983). Ingestion and incorporation of coral-mucus detritus by reef zooplankton. Mar. Biol 72: $211-218$

Hobbie, J. E., Daley, R. J., Jasper, S. (1977). Use uf Nuclepore filters for counting bacteria by fluorescence microscopy. Appl. environ. Microbiol. 35: 1225-1228

Hoppe, H.-G. (1983). Significance of exoenzymatic activities in the ecology of brackish water: measurements by means of methyl-umbelliferyl-substrates. Mar. Ecol. Prog. Ser. 11: 299-308

Hoppe, H. G. (1986). Relations between bacterial extracellular enzyme activity and heterotrophic substrate uptake in a brackish water environment. Deuxiéme Colloque International de Bacteriologie marine, Brest. Actes de Colloques du CNRS 3: 119-128

Hubbard, J. A., Pocock, Y. P. (1972). Sediment rejection by recent scleroctinian corals: a key paleoenvironmental reconstruction. Geol. Rundsch. 61: 598-626

Johannes, R. E., Wiebe, W. J., Crossland, C. J. (1983). Three patterns of nutrient flux in a coral reef community. Mar Ecol. Prog. Ser. 12: 131-136 
Linley, E. A. S., Koop, K. (1986). The significance of pelagic bacteria as a tropical resource in a coral reef lagoon. One Tree Island, Great Barrier Reef. Mar Biol. 92: 457-464

Meyer-Reil, L.-A., Schramm, W., Wefer, G. (1981). Microbiology of a tropical reef system (Mactan, Philippines). Kieler Meeresforsch., Sonderh. 5: 431-432

Moriarty, D. J. W (1979). Biomass of suspended bacteria over coral reefs. Mar. Biol. 53: 193-200

Moriarty, D. J. W., Pollard, P. C., Hunt, W. G. (1985a). Temporal and spatial variation in bacterial production in the water column over a coral reef. Mar. Biol. 85: 285-292

Moriarty, D. J. W., Pollard, P. C., Hunt, W. G., Moriarty, C. M. Wassenberg, T J. (1985b). Productivity of bacteria and microalgae and the effect of grazing by holothurians in sediments on a coral reef flat. Mar. Biol. 85: 293--300

Paul, J. H., DeFlaun, M. F., Jeffrey, W. H. (1986). Elevated levels of microbial activity in the coral surface microlayer. Mar. Ecol. Prog. Ser. 33: 29-40
Ryan, P. R. (1985). The underwater bush of Australia. The Great Barrier Reef. Oceanus 28: 31-42

Schleyer, M. H. (1981). Microorganisms and detritus in the water column of a subtidal reef of Natal. Mar. Ecol. Prog. Ser. $4: 307-320$

Schleyer, M. H. (1984). Heterotrophic utilization of a labelled algal extract in water samples from a tidal reef. Mar. Ecol. Prog. Ser. 16: 39-44

Schramm, W., Gualberto, E., Orosco, C. (1984). Release of dissolved organic matter from marine tropical reef plants: temperature and desiccation effects. Botanica mar. 27: $71-77$

Sorokin, Y. I. (1973). On the feeding of some scleractinian corals with bacteria and dissolved organic matter. Limnol. Oceanogr. 18(3): 380-385

Zimmermann, R., Meyer-Reil, L.-A. (1974). A new method for fluorescence staining of bacteria populations on membrane filters. Kieler Meeresforsch. 30: 24-27

This article was presented by Professor G. Rheinheimer; it was accepted for printing on February 4, 1988 